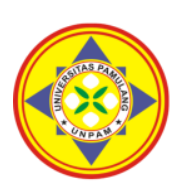

\title{
PENGARUH PELATIHAN DAN MOTIVASI KERJA TERHADAP KINERJA KARYAWAN PT. ASURANSI CENTRAL ASIA JAKARTA BARAT
}

\author{
1*Ading Sunarto, ${ }^{2}$ Damai Larasati \\ Universitas Pamulang, Tangerang Selatan, Banten, Indonesia \\ *dosen02153@unpam.ac.id
}

\begin{abstract}
Abstrak
Penelitian ini bertujuan untuk mengetahui seberapa besar Pengaruh Pelatihan dan Motivasi Kerja terhadap Kinerja Karyawan PT. Asuransi Central Asia.Metode penelitian adalah metode deskriptif kuantitatif, sedangkan untuk mendapatkan data dilakukan dengan menyebar kuesioner kepada 94 responden (karyawan). Populasi dalam penelitian ini adalah seluruh karyawan PT. Asuransi Central Asia. Teknik analisis data dengan Uji Validitas, Uji Reliabilitas,Uji Koefisien Korelasi, Uji Koefisien Determinasi dan Pengujian Hipotesis.Berdasarkan data yang diperoleh maka hasil dan pembahasan dalam penelitian mengetahui besar kecilnya pengaruh yang di olah menggunakan perhitungan SPSS versi 24. Hasil penelitian disimpulkan bahwa terdapat pengaruh yang signifikan antara Pelatihan dan Motivasi Kerja terhadap Kinerja Karyawan di PT. Asuransi Central Asia. Tingkat pengaruh atau kekuatan hubungannya sebesar 39,3\% sedangkan sisanya 60,7\% dipengaruhi faktor lain. Pengujian hipotesis diperoleh Fhitung> Ftabelyaitu 29,514> 3,10hal ini menunjukan bahwa terdapat pengaruh Pelatihan (X1) dan Motivasi Kerja (X2) secara simultan terhadap Kinerja Karyawan (Y).

Kata Kunci: Pelatihan, Motivasi Kerja, Kinerja Karyawan
\end{abstract}

This study aims to determine how much influence training and work motivation on employee performance at PT. Central Asia Insurance. The research method is descriptive quantitative method, while to obtain data is done by distributing questionnaires to 94 respondents (employees). The population in this study were all employees of PT. Central Asia Insurance. The data were analyzed by using the Validity Test, Reliability Test, Correlation Coefficient Test, Determination Coefficient Test and Hypothesis Testing. Based on the data obtained, the results and discussion in the study determine the size of the effect that is processed using the SPSS version 24 calculation. The results of the study concluded that there is a significant influence between Training and Work Motivation on Employee Performance at PT. Central Asia Insurance. The level of influence or strength of the relationship is $39.3 \%$ while the remaining $60.7 \%$ is influenced by other factors. Hypothesis testing obtained Fcount> Ftable, namely 29.514> 3.10, this shows that there is an effect of Training (X1) and Work Motivation (X2) simultaneously on Employee Performance $(Y)$.

Keywords: Training, Work Motivation, Employee Performance

\section{PENDAHULUAN}

Di era globalisasi ini setiap organisasi atau perusahaan saling bersaing menunjukkan keunggulan perusahaannya masing-masing.Persaingan yang terus menerus berkembang saat ini menuntut perusahaan untuk mampu bertahan dalam persaingan yang ada, serta mengembangkan setiap sumber daya manusia yang berkualitas.Keberhasilan kinerja sebuah organisasi sangat di pengaruh oleh kualitas faktor - faktor sumberdaya yang dimiliki, seperti faktor manusia, mesin, modal, pasar dan lain-lain. Namun di antara faktor-faktor tersebut kualitas sumber daya manusia memiliki peranan penting sebagai penggerak demi kelancaran jalannya suatu kegiatan. Tanpa adanya sumber daya manusia, maka sumber daya lainnya menjadi tidak berarti.

Perusahaan dituntut untuk memperoleh, mengembangkan dan mempertahankan SDM yang berkualitas. Pengelolaan sumber daya manusia yangdimaksudkan adalah bahwa perusahaan harus mampu untuk 
menyatukan persepsi atau cara pandang karyawan dan pimpinan perusahaan dalam rangka mencapai tujuan perusahaan dan meningkatkan kinerja perusahaan. Salah satu cara yang umum dilakukan perusahaan untuk menyatukan persepsi tersebut adalah dengan melalui pelatihan.

Pelatihan merupakan upaya yang berkaitan dengan peningkatan kemampuan atau keterampilan karyawan yang sudah menduduki suatu pekerjaan atau tugas tertentu. Dengan adanya pelatihan akan dapat menimbulkan perubahan yang lebih baik dalam kebiasaan bekerja, perubahan sikap, tingkah laku, keterampilan atau kemampuan serta pengetahuan karyawan.

Menurut Widodo (2015:82) pelatihan merupakan serangkaian aktivitas individu dalam meningkatkan keahlian dan pengetahuan secara sistematis sehingga mampu memiliki kinerja yang profesional dibidangnya. Pelatihan sangat dibutuhkan untuk karyawan baru ataupun karyawan yang naik jabatan, karena pada dasarnya karyawan tersebut memasuki lingkungan kerja yang lebih baik.

Pelatihan merupakan proses timbal balik yang bersifat membantu dan mereka yang dilatih harus aktif demi keberhasilan pelatihan tersebut agar tujuan perusahaan tercapai. Semakin banyak karyawan yang diberikan kesempatan untuk mengikuti pelatihan, maka dapat meningkatkan kemampuan dan keterampilan karyawan yang berkualitas demi tercapainya kinerja yang lebih baik.

PT Asuransi Central Asia (ACA) adalah perusahaan yang bergerak dibidang asuransi umum, yang merupakan salah satu perusahaan asuransi terbesar di Indonesia. Dengan jumlah seluruh karyawan mencapai seribuan lebih dari berbagai cabang, merupakan tantangan untuk melakukan pengelolaan sumber daya manusia secara optimal, demi menjaga kelangsungan hidup dan tercapainya tujuan perusahaan.

Oleh karena itu, PT. Asuransi Central Asia perlu menerapkan strategi penguatan internal untuk pemberdayaan sumber daya manusia secara sistematis dari tahun ke tahun. Strategi penguatan internal yang dimaksud adalah mengadakan beberapa program pelatihan untuk meningkatkan kompetensi karyawan agar sesuai dengan pekerjaan yang diemban. Pelaksanaan strategi ini dilakukan melalui kerja sama dengan berbagai instansi pendidikan dan konsultan terpercaya.

PT. Asuransi Central Asia menyelenggarakan pelatihan internal secara reguler dengan pengkhususan pada program peningkatan kompetensi di bidang marketing, managerial, interpersonal, dan yang terutama adalah teknik asuransi.Pelatihan diadakan di berbagai tempat seperti di kantor pusat PT. Asuransi Central Asia, di kantor cabang khusus, dan sebagian besar pelatihan tersebut diselenggarakan di Pusat Pendidikan dan Pelatihan PT. Asuransi Central Asia yang berlokasi di Puncak, Jawa Barat.

Berikut ini tabel data program pelatihan karyawan yang diadakan oleh PT. Asuransi Central Asia dari tahun 2016 sampai dengan tahun 2019:

Tabel 1. Data Program Pelatihan PT. Asuransi Central Asia

\begin{tabular}{|c|c|c|c|}
\hline Tahun & Target Program Jenis Pelatihan & Realisasi Program Pelatihan & Persentase \\
\hline 2016 & 80 Pelatihan & 62 Pelatihan & $77,5 \%$ \\
\hline 2017 & 80 Pelatihan & 28 Pelatihan & $35 \%$ \\
\hline 2018 & 80 Pelatihan & 28 Pelatihan & $35 \%$ \\
\hline 2019 & 80 Pelatihan & 35 Pelatihan & $43,75 \%$ \\
\hline
\end{tabular}

Sumber data: Laporan tahunan PT. Asuransi Central Asia tahun 2020

Berdasarkan data tersebut dapat 2016 sampai dengan tahun 2019. Penurunan dilihat pada tahun 2017 dan 2018 realisasi program pelatihan karyawan mengalami penurunan secara drastis yang diadakan oleh PT. Asuransi Central Asia dari tahun angka realisasi program pelatihan ini disebabkan karena adanya beberapa faktor seperti pengajar yang belum memadai, adanya permasalahan internal dan adanya 
tanah longsor di Puncak Bogor pada tahun 2017 dan tahun 2018 sehingga menyebabkan ditutupnya jalanan.

Fenomena ini dapat menunda tujuan pelatihan dikarenakan realisasi program pelatihan yang belum memenuhi target perusahaan. Semakin berkurang angka realisasi program pelatihan maka materi dan metode yang digunakan dalam program pelatihan pun akan berkurang. Dengan berkurangnya realisasi program pelatihan ini juga menyebabkan seluruh karyawan belum bisa mengikuti seluruh program pelatihan dan akan berpengaruh untuk kualifikasi peserta. Faktor pengajar yang belum memadai juga berpengaruh terhadap kualifikasi pelatih.

Selain pelatihan, hal yang terpenting bagi karyawan untuk meningkatan kinerja adalah motivasi. Motivasi adalah suatu proses yang mendorong atau mempengaruhi seseorang untuk mendapatkan atau mencapai apa yang diinginkannya. Motivasi untuk bekerja sangat penting bagi tinggi rendahnya kinerja perusahaan. Tanpa adanya motivasi dari para karyawan untuk bekerja sama bagi kepentingan perusahaan, maka tujuan yang telah ditetapkan tidak akan tercapai. Sebaliknya apabila terdapat motivasi kerja yang tinggi dari para karyawan, maka hal ini merupakan suatu jaminan atas keberhasilan perusahaan dalam mencapai tujuan.

Diberikannya motivasi kepada karyawan tentu saja mempunyai tujuan seperti mendorong semangat kerja karyawan, meningkatkan kinerja karyawan, mempertahankan loyalitas karyawan dan mempertinggi rasa tanggung jawab karyawan terhadap tugas dan pekerjaannya. Menurut Winardi (2016:6) motivasi merupakan suatu kekuatan potensial yang ada di dalam diri seorang manusia, yang dapat dikembangkannya sendiri atau dikembangkan oleh sejumlah kekuatan luar yang pada intinya berkisar sekitar imbalan moneter dan imbalan non moneter, yang dapat mempengaruhi hasil kinerjanya secara positif atau negatif.
PT. Asuransi Central Asia menetapkan beberapa upaya yang bertujuan untuk memotivasi kerja para karyawannya. Adapun upaya tersebut dengan memberikan beberapa fasilitas fasilitas kerja yang sangat menunjang dalam meningkatkan kinerja kepada seluruh karyawannya. Fasilitas - fasilitas tersebut meliputi pakaian kerja, tunjangan hari raya, asuransi, gaji, bonus dan sebagainya. Semua itu diberikan oleh perusahan, agar seluruh karyawan yang bekerja di dalamnya benar - benar terjamin sekaligus dapat menciptakan suatu motivasi yang baik guna mencapai tingkat kinerja yang diharapkan.

Motivasi akan memberikan perubahan pada seseorang yang muncul akibat dari perasaan, jiwa, dan emosi sehingga mendorong untuk melakukan tindakan sesuatu yang disebabkan karena kebutuhannya. PT. Asuransi Central Asia melakukan promosi (kenaikan pangkat) secara berjenjang untuk memenuhi kebutuhan akan prestasi karyawan, tetapi dilihat dari laporan tahunan PT. Asuransi Central Asia yang mendapatkan promosi di tahun 2019 hanya 112 orang dari 1.554 karyawan yang berarti masih banyak karyawan kurang motivasi untuk memenuhi kebutuhan akan prestasi. Fenomena ini juga akan menimbulkan kurangnya motivasi untuk memenuhi kebutuhan akan afiliasi karna sesama karyawan menjadi mempunyai perbedaan jenjang karir. Jika masih banyak karyawan yang belum mendapatkan promosi maka motivasi kebutuhan akan kekuasaan juga akan berkurang.

Berdasarkan uraian di atas, menjelaskan bahwa pelatihan dan motivasi kerja berhubungan dengan tingkat kinerja karyawan. Pada dasarnya, perusahaan tentu membutuhkan karyawan sebagai tenaga yangmeningkatkan produk dan layanan yang berkualitas. Mengingat karyawan dianggap merupakan bagian asset perusahaan yang penting dalam memberikan kontribusi kepada perusahaan untuk memperoleh kinerja yang baik serta mampu berkompetisi. Dalam pekerjaannya 
karyawan melakukan pekerjaan sesuai dengan kinerja yang dimiliki masingmasing setiap individu.

Kinerja adalah suatu hasil kerja seorang karyawan dalam suatu proses atau pelaksanaan tugasnya sesuai dengan tanggung jawabnya dan seberapa banyak pengaruhnya terhadap pencapaian tujuan perusahaan. Menurut Simanjuntak dalam Widodo (2015:131) kinerja merupakan tingkatan pencapaian hasil atas tugas tertentu yang dilaksanakan. Simanjuntak juga mengartikan kinerja individu sebagai tingkat pencapaian atau hasil kerja seseorang dari sasaran yang harus dicapai atau tugas yang harus dilaksanakan dalam kurun waktu tertentu. Kinerja adalah poin penting dalam kemajuan perusahaan, semakin meningkatnya kinerja karyawan suatu perusahaan maka semakin cepat tercapainya tujuan perusahaan tersebut.

Penilaian kinerja merupakan alat yang sering digunakan dalam mengukur kemampuan karyawan. Penilaian kinerja karyawan bermanfaat untuk melihat kontribusi karyawan terhadap perusahaan dan menjadi dasar perencanaan perusahaan untuk kedepan nantinya.Maka dari itu, berikut adalah data kinerja karyawan berdasarkan jumlah laba setelah pajak PT. Asuransi Central Asia dari tahun 2016 sampai tahun 2019:

Tabel 2. Data Jumlah Laba Setelah Pajak PT.

Asuransi Central Asia

\begin{tabular}{|c|lr|}
\hline Tahun & \multicolumn{2}{|c|}{ Jumlah Laba Setelah Pajak } \\
\hline 2016 & Rp. & $525,548,000,000$ \\
\hline 2017 & Rp. & $388,002,000,000$ \\
\hline 2018 & Rp. & $301,274,000,000$ \\
\hline 2019 & Rp. & $253,799,000,000$ \\
\hline \multicolumn{2}{|c|}{ Sumber data: Laporan Tahunan PT. Asuransi } \\
Central Asia tahun 2020
\end{tabular}

Berdasarkan data tersebut PT. Asuransi Central Asia memperoleh penurun laba setelah pajak selama 4 tahun terakhir. Laba setelah pajak tahun 2017 tercatat turun $26,17 \%$ dari $\operatorname{Rp} 525,55$ miliar pada tahun 2016 menjadi Rp 388 miliar pada tahun 2017 dan pada tahun 2018 tercatat turun 22,35\% menjadi Rp 301,27 miliar. Kemudian pada tahun 2019 pun menurun kembali 15,76\%dibanding tahun sebelumnya menjadi Rp. 253,79 miliar. Penurunan ini disebabkan biaya operasional perusahaan dari tahun 2016 sampai tahun 2019 meningkat setiap tahunnya.

Fenomena ini menunjukan rendahnya kinerja karyawan dari kualitas kerjadan kuantitas kerja yang ditunjukan oleh fluktuasi jumlah laba setelah pajak selama empat tahun terakhir. Yang berarti tanggung jawab dari karyawan juga belum maksimal karna tidak mencapai tujuan perusahaan yang lebih meningkat. Sebaiknya karyawan lebih meningkatkan kerjasama antar karyawan dan membuat inisiatif agar perusahaan lebih maju.

Setiap perusahaan selalu menginginkan kinerja dari setiap karyawannya meningkat. Kinerja karyawan pada dasarnya terbentuk setelah karyawan merasa adanya kepuasan, karena kebutuhannya terpenuhi dengan kata lain apabila kebutuhan karyawan belum terpenuhi sebagaimana mestinya maka kepuasan kerja tidak akan tercapai dan pada hakikatnya kinerja pegawai akan sulit terbentuk.

Berdasarkan fenomena permasalahan yang terjadi dan data-data yang telah dihimpun serta rangkaian penjelasan tentang pelatihan dan motivasi kerja karyawan maka terdapat suatu permasalahan. Oleh karena itu, penulis mengambil judul penelitian untuk skripsi yaitu "Pengaruh Pelatihan dan Motivasi Kerja Terhadap Kinerja Karyawan PT. Asuransi Central Asia Jakarta Barat".

\section{TINJAUAN PUSTAKA}

\section{Pelatihan}

Menurut Andrew E. Sikula dalam A.A Anwar Prabu Mangkunegara (2013:44) pelatihan adalah suatu proses pendidikan jangka pendek yang mempergunakan prosedur sistematis dan terorganisir dimana pegawai non manajerial mempelajari pengetahuan dan keterampilan teknis dalam tujuan terbatas.

Sedangkan Menurut Ivancevich dalam Edy Sutrisno (2016:67) pelatihan 
adalah usaha untuk meningkatkan prestasi kerja (kinerja) karyawan dalam pekerjaannya sekarang atau dalam pekerjaan lain yang akan dijabatnya segera. Pelatihan menurut Widodo (2015:82)merupakan

serangkaianaktivitas individu dalam meningkatkan keahlian dan pengetahuan secarasistematis sehingga mampu memiliki kinerja yang professionaldi bidangnya.Pelatihan adalah proses pembelajaran yang memungkinkan pegawaimelaksanakan pekerjaan yangsekarang sesuai dengan standar.

Berdasarkan pada pendapat para ahli diatas, dapat di katakan bahwa pelatihan adalah suatu alat manajemen sumber daya manusia yang digunakan untuk memperoleh keahlian, keterampilan, atau sikap karyawan dalam rangka meningkatkan kinerja karyawan. Karyawan, baik yang baru ataupun yang sudah bekerja perlu mengikuti pelatihan karena adanya tuntutan pekerjaan yang dapat berubah

\section{Motivasi}

Secara ringkas, Pengertian Motivasi merupakan suatu perubahan yang terjadi pada diri seseorang yang muncul adanya gejala perasaan, kejiwaan dan emosi sehingga mendorong individu untuk melakukan atau bertindak sesuatu yang disebabkan karena kebutuhan, keinginan dan tujuan.

Beberapa pendapat mengenai motivasi menurut para ahli, Winardi mengemukakan (2016:6) bahwa motivasi merupakan suatu kekuatan potensial yang ada di dalam diri seorang manusia, yang dapat dikembangkannya sendiri atau dikembangkan oleh sejumlah kekuatan luar yang pada intinya berkisar sekitar imbalan moneter dan imbalan non moneter, yang dapat mempengaruhi hasil kinerjanya secara positif atau negatif. Sedangkan yang dikemukakan oleh Malayu (2015:23) pengertian motivasi adalah mempersoalkan bagaimana cara mendorong gairah kerja bawahan, agar mereka mau bekerja keras dengan memberikan semua kemampuan dan keterampilan untuk mewujudkan tujuan perusahaan.

Berdasarkan definisi menurut para ahli di atas dapat disimpulkan bahwa motivasi karyawan adalah dorongan dari dalam diri maupun dari luar diri seseorang untuk melakukan suatu tindakan untuk mencapai suatu tujuan yang telah ditentukan dalam sebuah organisasi.

\section{Kinerja}

Mangkunegara pengertian kinerja (prestasi kerja) adalah hasil kerja secara kualitas dan kuantitas yang dicapai oleh seorang pegawai dalam melaksanakan tugasnya sesuai dengan tanggung jawab yang diberikan kepadanya. Menurut Wirawan dalam Abdullah (2014:3) kinerja merupakan singkatan dari kinetika energi kerja yang padanannya dalam bahasa inggris adalah perfomance, kinerja adalah keluaran yang dihasilkan oleh fungsifungsi atau indikator-indikator suatu pekerjaan atau suatu profesi dalam waktu tertentu. Nawawi dalam Widodo (2015:131) kinerja adalah hasildari suatu pekerjaan yang telah dilakukan, baik berupa fisik atau material maupun non fisik atau non material. Menurut Simanjutak dalam Widodo (2015:131) kinerja merupakan tingkatan pecapaian hasil atas tugas tertentu yang dilaksanakan. Simanjutak juga mengartikan kinerja individu sebagai tingkat pencapaian atau hasil kerja seseorang dari sasaran yang harus dicapai atau tugas yang harus dilaksanakan dalam kurun waktu tertentu.

Berdasarkan beberapa pengertian diatas maka dapat disimpulkan kinerja adalah hasil yang diperoleh seseorang dalam melakukan pekerjaannya dalam waktu tertentu sesuai dengan tanggung jawab yang telah diberikan oleh suatu 
organisasi.

\section{METODE}

Jenis penelitian ini adalah metode deskriptif kuantitatif dengan pendekatan asosiatif Populasi dalam penelitian ini adalah karyawan PT Asuransi Central Asia yang berjumlah 1.543 karyawan (per Maret 2020). Sampel dalam penelitian menggunakan rumus Slovin didapat 94 responden. Jenis penelitian yang dipakai adalah kuantitatif, dimana tujuannya adalah untuk mengetahui pengaruh antara variabel bebas terhadap variabel terikat baik parsial maupun simultan Dalam menganalisis data digunakan uji instrumen, uji asumsi klasik, regresi, koefisien korelasi, koefisien determinasi dan uji hipotesis.

\section{HASIL DAN PEMBAHASAN}

Setelah diketahui hasil temuan dalam penelitian ini dan kemudian dianalisis seberapa baik data tersebut merepresentasikan penelitian yang diangkat, terutama kemampuan dalam menjelaskan seberapa baik Pelatihan dan Motivasi Kerja terhadap Kinerja Karyawan. Selanjutnya akan dilakukan pembahasan terkait hasil temuan - temuandalam penelitian ini.

\section{Variabel Pelatihan}

Berdasarkan analisis deskriptif diperoleh nilai rata-rata yaitu 4,18 atau berada di kategori skala (3,41 4,20:Tinggi/Baik) dimana tanggapan responden terhadap variabel Pelatihan (X1) memiliki kategori skala Baik,dilihat dari skor tertinggi 4,28yaitu pada pernyataan"Materi pelatihan yang diberikan sesuai dengan pekerjaan".

Berdasarkan hasil uji validitas 10 item kuisioner memiliki nilai corrected item total correlation lebih besar dari $0,2006\left(r_{\text {hitung }}>r_{\text {tabel }}\right)$ berarti seluruh butir pernyataan variabel Pelatihan(X1) dinyatakan Valid.

Berdasarkan hasil uji reliabilitas maka item kuisioner $r_{c a}(0,906)>r_{\text {tabel }}$ $(0,600)$ dengan ketentuan $a=5 \%$ maka besar $r_{\text {tabel }}=0,6$ (Sugiyono (2013:184)), maka varians butir item variable Pelatihan $\left(X_{1}\right)$ dapat dinyatakan Reliabel. Hasil uji parsial (uji t) antara Pelatihan terhadap Kinerja Karyawanmenunjukan nilai $t_{\text {hitung }}>t_{\text {tabel }}$ $(5,745>1,98638)$ dan sig $<0,05(0,000<$ $0,05)$ sehingga $\mathrm{Ho}_{1}$ di tolak dan $\mathrm{Ha}_{1}$ diterima yaitu "terdapat pengaruh Pelatihanterhadap Kinerja Karyawan". Hasil penelitian ini sejalan dengan penelitian yang dilakukan oleh Daru Suryantiko \& Genita Lumintang (2018), Priskila Makian (2016), Sohib Muhammad Muhibin (2018), Hery Suprayitno (2019), Aden Prawiro Sudarso (2019) serta Mulyadi (2018)ada pengaruh positif dan signifikan secara parsial antara variable Pelatihan terhadap Kinerja Karyawan.

\section{Variabel Motivasi Kerja}

Berdasarkan analisis deskriptif maka terlihat nilai rata-rata yaitu 4,05 atau di berada di kategori skala (3,41 4,20: Tinggi/Baik) dimana tanggapan responden terhadap variabel Motivasi $\operatorname{Kerja}(\mathrm{X} 2)$ memiliki kategori skala Baik,dilihat dari skor tertinggi 4,23 yaitu pada pernyataan "Saya giat bekerja dikarenakan adanya kesempatan yang diberikan untuk menduduki posisi tertentu."

Berdasarkan hasil uji validitas 10 item kuisioner variabel Motivasi Kerjamemiliki nilai corrected item total correlation lebih besar dari 0,2006( $\left.\mathrm{r}_{\text {hitung }}>\mathrm{r}_{\text {tabel }}\right)$ berarti seluruh butir pernyataan variabel Motivasi $\operatorname{Kerja}(\mathrm{X} 2)$ dinyatakan Valid.

Berdasarkan hasil uji reliabilitas maka item kuisioner $r_{c a}(0,893)>r_{\text {tabel }}$ $(0,600)$ dengan ketentuan $\alpha=5 \%$ maka besar $r_{\text {tabel }}=0,6$ (Sugiyono (2013:184)), maka varians butir item variable Motivasi Kerja (X2) dapat dinyatakan Reliabel.

Hasil uji parsial (uji t) antara Motivasi Kerjaterhadap Kinerja Karyawan menunjukan nilai $t_{\text {hitung }}>t_{\text {tabel }}$ $(7,520>1,98638)$ dan sig $<0,05(0,000<$ $0,05)$ sehingga $\mathrm{Ho}_{2}$ ditolak dan $\mathrm{Ha}_{2}$ diterimayaitu 
pengaruhMotivasi Kerjaterhadap

Kinerja Karyawan". Hasil penelitian ini sejalan dengan penelitian yang dilakukan oleh Priskila Makian (2016), Novi Susanti (2019), Sohib Muhammad Muhibin (2018), Said Abdi Mohamud (2017), Mulyadi (2018), Ading Sunarto (2020) serta Sam Cay (2019)ada pengaruh positif dan signifikan secara parsial antara variable Motivasi Kerja terhadap Kinerja Karyawan.

\section{Variabel Kinerja Karyawan}

Berdasarkan analisis deskriptif maka terlihat nilai rata-rata yaitu 3,87 atau di berada di kategori skala (3,41 4,20: Tinggi/Baik) dimana tanggapan responden terhadap variabel Kinerja Karyawan (Y) memiliki kategori skalaBaik,dilihat dari skor tertinggi 4,23 yaitu pada pernyataan "Saya tidak pernah menunda - nunda pekerjaan yang atasan berikan."

Disamping itu pihak perusahaan harus lebih meningkatkan tingkat Kinerja Karyawan pada indikator kerjasama karena masih terdapat skor rendah sebesar 3,21 yaitu pada pernyataan "Saya siap membantu rekan kerja saya apabila ada yang kesulitan dalam menyelesaikan pekerjaanya."

Berdasarkan hasil uji validitas 10 item kuisioner variabel Kinerja Karyawanmemiliki nilai corrected item total correlation lebih besar dari 0,2006( $\left.\mathrm{r}_{\text {hitung }}>\mathrm{r}_{\text {tabel }}\right)$ berarti seluruh butir pernyataan variabel Kinerja Karyawan(Y) dinyatakan Valid.

Berdasarkan hasil uji reliabilitas variabel Kinerja Karyawan item kuisioner $r_{c a}(0,893)>r_{\text {tabel }}(0,600)$ dengan ketentuan $\alpha=5 \%$ maka besar $r_{\text {tabel }}=0,6$ (Sugiyono (2013:184)), maka varians butir item variabel Kinerja Karyawan (Y) dapat dinyatakan Reliabel.

Dari hasi uji $\mathrm{F}$ dapat diperoleh nilai $\mathrm{F}_{\text {hitung }}>\mathrm{F}_{\text {tabel }}$ yaitu $29,514>3,10$ dan nilai sig $<0,05$ atau 0,000 $<0,005$ hal ini menunjukan "terdapat pengaruh Pelatihandan Motivasi Kerjasecara simultan terhadapKinerja Karyawan". Hasil penelitian ini sejalan dengan penelitian yang dilakukan oleh Priskila Makian (2016) dan Mulyadi (2018)ada pengaruh positif dan signifikan secara simultan antara variable Pelatihan dan Motivasi Kerja terhadap Kinerja Karyawan.

\section{PENUTUP \\ Kesimpulan}

Berdasarkan hasil pembahasan mengenai pengaruh pelatihan dan motivasi kerja terhadap kinerja karyawan PT. Asuransi Central Asia, maka dapat disajikan beberapa kesimpulan dari hasil analisis yaitu sebagai berikut:

1. Berdasarkan penelitian untuk variabel pelatihan memiliki pengaruh positif dan signifikan terhadap kinerja karyawan. Hal ini terlihat dari angka $t_{\text {hitung }}>t_{\text {tabel }}$ yakni $5,745>1,98638$ dan tingkat signifikansinya lebih kecil dari 0,05 sehingga menyebabkan hipotesis dari pengaruh pelatihan terhadap kinerja karyawan diterima.

2. Berdasarkan penelitian untuk variabel motivasi kerja memiliki pengaruh positif dan signifikan terhadap kinerja karyawan. Hal ini terlihat dari angka $t_{\text {hitung }}>t_{\text {tabel }}$ yakni $7,520>1,98638$ dan tingkat signifikansinya lebih kecil dari 0,05 sehingga menyebabkan hipotesis dari pengaruh motivasi kerja terhadap kinerja karyawan diterima.

3. Berdasarkan penelitian untuk variabel pelatihan dan motivasi kerja memiliki pengaruh positif dan signifikan terhadap kinerja karyawan. Hal ini terlihat dari angka $F_{\text {hitung }}>F_{\text {tabelyakni } 29,514>3,10}$ dan tingkat signifikansinya lebih kecil dari 0,05 sehingga menyebabkan hipotesis dari pengaruh pelatihan dan motivasi kerja terhadap kinerja karyawan diterima.

\section{Saran}

Saran yang dapat penulis kemukakan sehubung dengan hasil penelitian dan pembahasan yang dilakukan adalah:

1. Dimana pihak perusahaan harus lebih meningkatkan kualitas pelatihan dalam segi kualifikasi pelatih agar peserta atau 
karyawan yang mengikuti pelatihan dapat mudah memahami materi.

2. Dimana pihak perusahaan harus lebih memperhatikan karyawannya untuk mengikut sertakan karyawan dalam kegiatan - kegiatan penting di perusahaan agar motivasi kerja dalam kebutuhan akan afiliasi terpenuhi.

3. Dimana pihak perusahaan harus lebih memperhatikan karyawannya untuk dapat membantu sesama rekan kerja agar kerjasama di perusahaan semakin lebih baik.Diharapkan dalam penelitian selanjutnya agar menambahkan variabel lainnya yang mungkin berpengaruh terhadap penelitian seperti prestasi kerja, disiplin atau stress kerja.

\section{DAFTAR PUSTAKA}

Abdullah, M. (2014). Manajemen dan Evaluasi Kinerja Karyawan. Yogyakarta: Penerbit Aswaja Pressindo.

Anonim. (2019). Laporan Tahunan PT. Asuransi Central Asia. Jakarta.

Arikunto, Suharsimi. (2010). Prosedur Penelitian Suatu Pendekatan Praktek. Jakarta: Rineka Cipta.

Bintoro dan Daryanto. (2017).Manajemen Penilaian Kinerja Karyawan. Cetakan I. Yogyakarta: Gava Media.

Cay, Sam. (2019). Pengaruh Komunikasi, Motivasi Kerja Dan Stres Kerja Terhadap Guru Al Azhar BSD. KREATIF: Jurnal Ilmiah Prodi Manajemen Universitas Pamulang, 6(4), 2339-0689.

Darmadi, Hamid. (2013). Metode Penelitian Pendidikan dan Sosial. Bandung: Alfabeta.

Eka, P. D. (2020). Analisis Pengaruh Keselamatan Kerja Dan Pelatihan Terhadap Kinerja Karyawan Pada PT Berca Schindler Lifts Project Alfa Tower Tangerang. JENIUS (Jurnal Ilmiah Manajemen Sumber Daya Manusia), 3(2), 198-207.

Makian, Priskila. (2016). Pengaruh Pengaruh Pelatihan Kerja dan Motivasi Kerja terhadap Kinerja KaryawanPT. PCI Elektronik
International. Jurnal Akuntansi, 4(1), 2337-7887.

Mohamud, Said Abdi. (2017). The Effect of Motivation on Employee Performance: Case Study in Hormuud Company in Mogadishu Somalia. International Journal of Development Research, 7(11), 2230-9926.

Muhibin, Sohib Muhammad. (2018). Pengaruh Pendidikan dan Pelatihan serta Motivasi Kerja Terhadap Kinerja Karyawan PT. Asuransi Jasa Indonesia (Persero). Jurnal Manajemen Bisnis Krisnadwipayana, 6(2), 2338-4794.

Mulyadi. (2018). Pengaruh Pelatihan dan Motivasi Terhadap Kinerja Karyawan PT. Permata Lestari. JENIUS: Jurnal Ilmiah, Manajemen Sumber Daya Manusia, 2(1), 2581-2769.

Nurhayati, N. I. D. N., Hindarsah, I., Sos, S., Erlangga, H., Sos, S., \& Maun Jamaludin, I. (2018). Pelatihan Pembukuan Di UKM Sumpia Chantika Dewi Cimindi Cimahi. Laporan Program Kepakaran Fisip Unpas Pengabdian Kepada Masyarakat Tahun Akademik 2016/2017, $1-22$.

Nurjaya, N., Affandi, A., Ilham, D., Jasmani, J., \& Sunarsi, D. (2021). Pengaruh Kompetensi Sumber Daya Manusia Dan Kemampuan Pemanfaatan Teknologi Terhadap Kinerja Aparatur Desa Pada Kantor Kepala Desa Di Kabupaten Gunungkidul, Yogyakarta. JENIUS (Jurnal Ilmiah Manajemen Sumber Daya Manusia), 4(3), 332-346.

Permatasari, R. J. (2018). Analisis Pengaruh Pendidikan Dan Pelatihan, Motivasi Dan Kompensasi Terhadap Kinerja Karyawan (Pada Citibank Pondok Indah Jakarta Selatan). JENIUS (Jurnal Ilmiah Manajemen Sumber Daya Manusia), 1(3).

Rawi, R. D. P. (2017). Analisis Hubungan Motivasi Terhadap Kinerja Pegawai (Studi Kasus Pada Kantor Kecamatan Ruing Kabupaten Ngada Ntt). Jurnal Noken: Ilmu-Ilmu Sosial, 2(2), 15-28. 
Santoso, Singgih. (2012). Panduan Lengkap SPSS Versi 20. Jakarta: PT Elex Media Komputindo.

Sudarso, Aden Prawiro. (2019). Pengaruh Pelatihan Kerja Terhadap Kinerja Karyawan PT. Hero Supermarket Tbk Cabang Pondok Indah. Jurnal Ekonomi Efektif, 2(1), 2662-8882.

Sudjana, Nana. (2011). Penilaian Hasil Proses Belajar Mengajar. Bandung: PT Remaja Rosdakarya.

Sugiyono. (2011). Metode Penelitian Kuantitatif, Kualitatif dan R\&D. Bandung: Alfabeta.

Sunarto, A. (2020). Kinerja Karyawan Berbasis Kepemimpinan Dan Motivasi Pada PT. Duta Jaya Putra Persada Mining. JENIUS (Jurnal Ilmiah Manajemen Sumber Daya Manusia), 3(3), 246-257.

Sunarto, A. (2020). Pengaruh Gaya Kepemimpinan, Motivasi, Serta Disiplin Kerja Terhadap Kinerja Karyawan (study di PT Mitsui Leasing Capital Indonesia Abdul Muis - Jakarta Pusat). KREATIF: Jurnal Ilmiah Prodi Manajemen Universitas Pamulang, 8(1), 18-38.

Sunarto, A., Qurbani, D., \& Virby, S. (2020). Pengaruh Kompetensi, Disiplin Kerja Dan Lingkungan Kerja Terhadap
Kinerja Pada PT Anugrah Bersama Sejahtera Depok. JIMF (Jurnal Ilmiah Manajemen Forkamma), 4(1).

Sunarto, A., Tanjung, A. W., \& Ellesia, N. (2020). Teacher Performance Based on The Visionary Leadership Style of School, Competency and Work Discipline (Study at Muhammadiyah Setiabudi Pamulang College). Journal of Research in Business, Economics, and Education, 2(5), 1046-1052.

Suprayitno, Hery. (2019). Pengaruh Pelatihan Dan Pengembangan Sumber Daya Manusia Terhadap Peningkatan Etos Kerja Karyawan Bank Bukopin Cabang Bogor. Seminar Nasional HUMANIS, 1(1), 2746-2250.

Suryantiko, Daru \& Lumintang, Genita. (2018). Pengaruh Pelatihan Kerja dan Pengembangan Karir terhadap Kinerja Karyawan PT. Air Manado. Jurnal EMBA, 6(1), 351-360.

Susanti, Novi. (2019). Pengaruh Stress Kerja dan Motivasi Kerja terhadap Kinerja Karyawan pada PT. Tirta Mahakam Resource Tbk Samarinda. Jurnal Ekonomi, 20(2), 1412-6877.

Winardi. (2016). Kepemimpinan dalam Manajemen. Jakarta: PT. Rineka Cipta. 